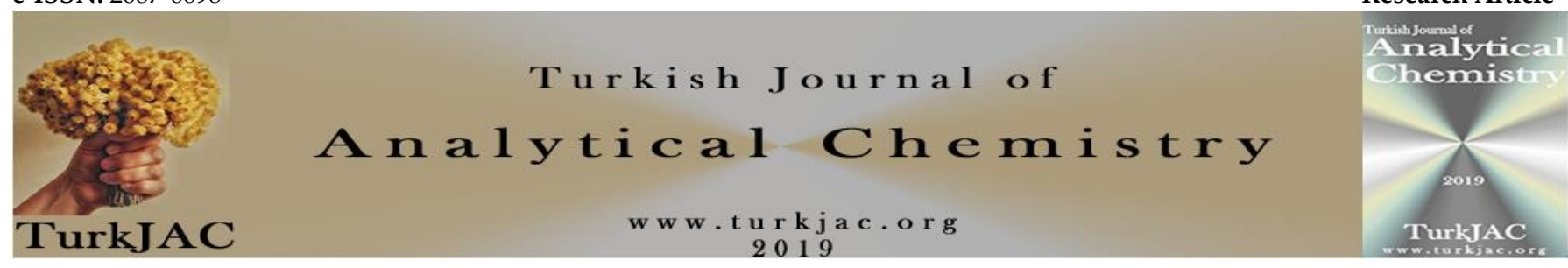

\title{
Designing potential HIV-1 integrase inhibitors: An in silico approach
}

\section{Arif Mermer* iD}

*University of Health Sciences-Turkey, Experimental Medicine Research and Application Center, Uskudar, 34662, Istanbul, Turkey

\begin{abstract}
Human immunodeficiency virus is a spectrum of conditions caused by infection with the human immunodeficiency virus. In 2019 , about 38 million people worldwide were living with HIV and 690,000 deaths had occurred in that year. To date, for the treatment of HIV-1 disease, many compounds have been synthesized and some of them were approved by FDA. However, the use of these drugs has been limited due to reasons such as resistance caused by the misuse of drugs and bad side effects. We describe herein designing 48 novel compounds as a potential inhibitor of HIV-1 integrase through in silico studies such as molecular docking, target analysis, toxicity prediction, and ADME prediction. The online webbased platform, SwissADME, also predicts these molecules' solubility, pharmacodynamics property, and target accuracy.
\end{abstract}

Keywords: Swissadme, HIV-1 integrase, molecular docking, in silico study, toxicity

\section{Introduction}

HIV-1 integrase (IN) represents a charming aim in antiHIV drug design fundamentally because of its specificity. Hence, HIV-1 IN does not possess a functional equivalent in humans and exhibits a crucial role in forming irreversible and productive viral infections [1]. This enzyme catalyzes the insertion of proviral DNA, obtained from reverse transcription of HIV-1 RNA, into the genome of the host-infected cells. The insertion is carried through a two-step enzymatic phase which is endonucleolytic cleavage of a terminal dinucleotide (GT) and "strand transfer" (ST). Consequently, both reactions are finalized by the catalytic core domain of HIV-1 IN which includes two divalent metal ion cofactors $\left(\mathrm{Mg}^{2+}\right)$. These metal ions are coordinated by three catalytic carboxylate residues: Asp64, Asp116, and Glu152 (DDE triad) within the enzyme active site [2]. To aim the metal cofactors within the active site of a viral metal-activated enzyme-like HIV-1 IN has shown up as an appealing and confirmed strategy for the improvement of novel anti-HIV agents. For this purpose, a metal-binding pharmacophore model has been utilized to design novel HIV-1 IN inhibitors as given in Fig. 1A. Two distinctive features are particularly taken into account in this model: the first is a planar metal binding site that can interact with metals present in the enzyme's active site, while the second is the

Citation: A. Mermer, Designing Potential HIV-1 Integrase Inhibitors: An in Silico Approach, Turk J Anal Chem, 3(2), 2021, 45-53. presence of an aromatic or heteroaromatic hydrophobic functional group located close to the metal-binding site $[3,4]$. Constant workings in using this pharmacophore model have ended up the design and following FDA approval of three INIs for clinical use as potent anti-HIV drugs: Raltegravir (RLT), Elvitegravir (EVG), and Dolutegravir (DTG) in 2007, 2012, and 2013, respectively (Fig. 1B) [5-7].

Various MBGs have been widely researched to design progressive and potent INIs [8,9]. Isonaphthylic acid (INA) derivatives can potentially be studied as novel HIV-1 IN inhibitors due to the metal-binding sites in their structure. Thus, INA derivatives represent an effective class of aromatic ligands with powerful bidentate chelating capacity toward metal ions. Moreover, the presence of an amide group as a linker plays an important role in the inhibitory activity of these types of compounds. And an aromatic functional group linked to the amide is considered for ensuring the basic interactions with the hydrophobic pocket of the enzyme [10].

In drug discovery studies, many parameters such as which reactants to be used in which amount, substituent selection, and whether they are biologically active or not are evaluated in order to avoid time and resource

\footnotetext{
*Author of correspondence: arfmermer@hotmail.com

Tel: +90 (216) 4189616

Fax +90 (216) 4189620

Received: 09 June, 2021

Accepted: 14 October, 2021 


\section{A}

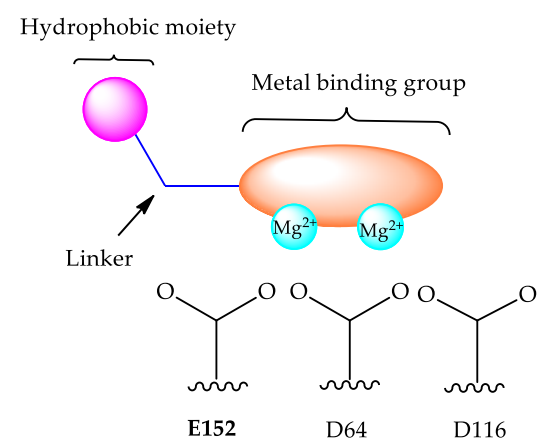

B<smiles>Cc1nnc(C(=O)NC(C)(C)c2nc(C(=O)NCc3ccc(F)cc3)c(O)c(=O)n2C)o1</smiles>

Raltegravir<smiles>COc1cc2c(cc1Cc1cccc(Cl)c1F)c(=O)c(C(=O)O)cn2[C@@H](CO)C(C)C</smiles>

Elvitegravir<smiles>C[C@H]1CCOC2Cn3cc(C(=O)NCc4ccc(F)cc4F)c(=O)c(O)c3C(=O)N21</smiles>

Dolutegravir Hit to lead compounds<smiles>[R][X]c1ccccc1CCNC(=O)c1cc(C)cc(C(=O)NCC([Y7])c2ccccc2)c1O</smiles>

Figure 1. Demonstration of the pharmacophore model for HIV-1 INs. (B) FDA-approved drugs against HIV-1 INIs. Atoms marked with blue of MBG of the drugs can chelate the $\mathrm{Mg}^{2+}$ ions. The hydrophobic part of the compounds is marked with red

consumption. The molecule to be synthesized must have high activity and low toxicity at the same time. Equally significant is the access to and concentration at the therapeutic target in the organism. The conventional step to consider pharmacokinetics is to separate the diverse impacts that influence the access to the target into individual parameters. In this context, these ADMET parameters (for absorption, distribution, metabolism, excretion, and toxicity) can be evaluated separately by dedicated methods. In drug design and discovery studies, it has been dedicated that the early estimation of ADMET properties greatly reduces the potential disadvantages in clinical and phase stages. Computer models have been encouraged as an effective alternative to experimental procedures for the estimation of ADME, particularly at early steps, when researched chemical structures are countless but the availability of compounds is limited [11,12].

The SwissADME is a web-based platform that is freely accessible at http://www.swissadme.ch and it can be simply used even by non-experts in computer-aided drug design (CADD) studies and the results can be easily analyzed. Compared to other web-based tools for determining ADME and pharmacokinetic properties, SwissADME key points are, partially: various input ways, computation for multiple compounds, and the opportunity to show, save and share outcomes per individual compounds or through global intuitive and interactive graphs. Consequently, SwissADME is combined with the SwissDrugDesign field. One-click interoperability gains access to different CADD tools improved by the Molecular Modeling Group of the SIB Swiss Institute of Bioinformatics, e.g., ligand-based virtual screening, bio target prediction, molecular docking, bioisosteric design, or molecular mechanics [13-21].

In the light of the above considerations, this paper includes in silico analysis of 48 novel HIV-1 IN inhibitors, containing different substituents and linkers such as fluorine, chlorine, bromide, methoxy, which is provided 
with the target protein's inhibition site (PDB ID: 1QS4), prediction of ADME, Target Prediction were done by using SwissBioinformatics online Tools. The prediction of toxicity of designing compounds was screened via the pkCSM online web tool. Furthermore, the molecular docking studies of the most potent compound were performed.

\section{Materials and Methods}

\subsection{Molecular Docking}

The co-crystallized structure of HIV-1 integrase enzyme [PDB: 1QS4] was taken from Protein Data Bank (PDB) and prepared by utilizing the Protein Preparation Wizard Module of Schrödinger Software Suite. Then it was optimized by removing the water molecules, heteroatoms, and co-factors. The hydrogens, missing atoms, bonds, and charges were computed through Maestro [26, 27]. Compound 24 exhibited the highest drug-likeness score was selected for docking study. The ligand preparation and optimization contain forming different tautomers, assigning bond orders, ring conformations that were minimized using the OPLS2005 force field before the docking study, and stereochemistries were performed via the LigPrep module of Schrödinger Software Suite. Besides, a receptor grid was formed around the co-crystallized ligand of the enzyme. The grid box size was set to $20 \AA$ Radius, using the receptor Grid Generation applied in Glide. Extra Precision (XP) mode and Glide programs were used for the docking calculations [28-30].

\subsection{ADME Prediction}

ADME (adsorption, distribution, metabolism, and excretion) is significant to search the pharmacodynamics of the designed compounds which could be a target agent in drug design and discovery studies. SwissADME is a web-based platform that lets the user upload or draw their hit compounds with structure or SMILES code. This tool supplies many parameters such as lipophilicity (iLOGP, XLOGP3, WLOGP, MLOGP, SILICOS-IT, Log

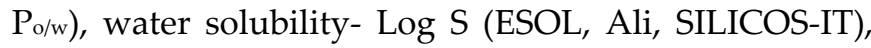
drug-likeness rules (Lipinski, Ghose, Veber, Egan, and Muegge) and Medicinal Chemistry (PAINS, Brenk, Leadlikeness, Synthetic accessibility) methods [22]. The designed novel HIV-1 IN inhibitors were uploaded with SMILES codes and analyzed.

\subsection{Target Prediction}

Molecular Target investigations are crucial to determine the phenotypical side effects or potential cross-reactivity induced by the action of bioorganic compounds of which molecular weight is not bigger than $500 \mathrm{~g} / \mathrm{mol}$ [23]. The designed compound's SMILES codes were uploaded to the Swiss Target Prediction website in order to analyze their target prediction (https://www.swisstargetprediction.ch).

\subsection{Toxicity Prediction}

Toxicology prediction of bioorganic compounds is substantial to estimate the amount of tolerability of the hit compounds before in vitro, in vivo, and clinical studies. pkCSM is also a web-based platform for analyzing physicochemical properties of small compounds, and this online website supplies many toxicology results such as LD50, hERG-I inhibitor, AMES Toxicity, hERG-II inhibitor, human maximum tolerated dose, LOAEL, Skin Toxicity, T. pyriformis toxicity, Hepatotoxicity, and Minnow toxicity. The designed compounds' SMILES codes were uploaded pkCSM website to analyze their target prediction (http://biosig.unimelb.edu.au/pkcsm/) [24].

\section{Results and Discussion}

\subsection{Molecular Docking}

Considering the ADME and toxicity outcomes, a deep docking study was implemented to regard the possible binding modes of the promising compound (24) inside the active site of HIV-1 integrase enzyme (PDB ID: 1QS4) by using Schrödinger Software. Initially, the cocrystalized ligand 1-(5-chloroindol-3-yl)-3-hydroxy-3(2H-tetrazol-5-yl)-propenone (CCL) and the protein (PDB ID: 1QS4) were modeled to validate the Glide. Superimposition of the experimental bound (cocrystallized) conformation of 1-(5-chloroindol-3-yl)-3hydroxy-3-(2H-tetrazol-5-yl)-propenone estimated by Glide. The experimental binding conformations of cocrystalized ligand in the binding pocket of 1QS4 were successfully generated with an acceptable root-meansquare deviation (RMSD) of $0.175 \AA(<2 \AA)$ [31]. The interactions between co-crystallized ligand and the active site of HIV-1 IN was shown in Fig. 2A. Compound 24 and its interactions with the binding side of 1QS4 were demonstrated in Fig. 2B. Hereby, compound 24 was surrounded with LYS 159, LYS 156, ASN 155, GLU 152, ILE 151, GLY 149, and GLN 148 amino acid residues of the active site of HIV-1 IN enzyme. Further, the carbonyl group of amide generated a strong hydrogenbonding interaction with ASN 155, and the hydroxy group between two amide bonds in the phenyl ring formed a strong hydrogen-bonding interaction with ASP 64 . The docking score of the chosen compound and cocrystallized ligand were given in Table 1. 

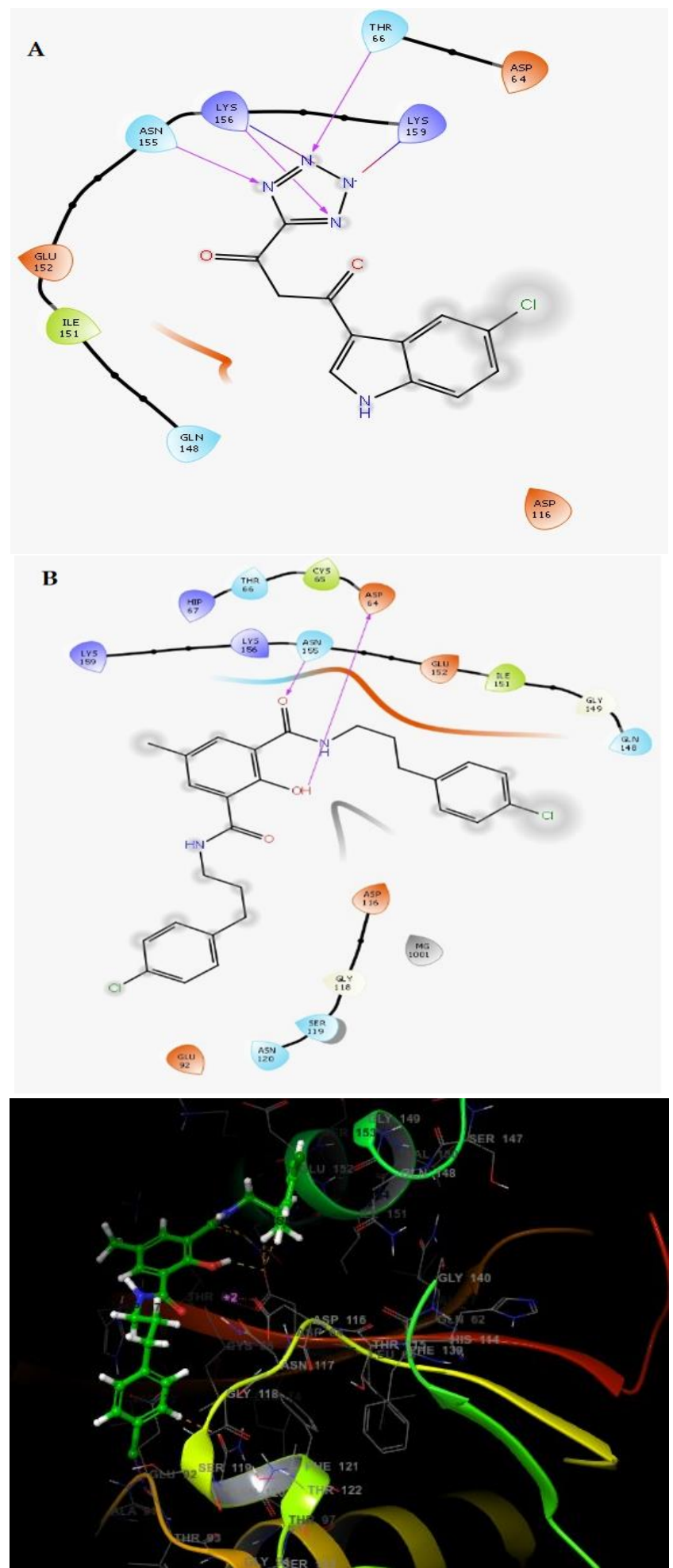

Figure 2. A: Co-crystallized ligand and its interaction of active site of HIV-1 IN, B: Compound 24 and its interaction of active site of HIV-1 IN

Table 1. The docking scores the chosen compound, co-crystallized ligand and its binding interactions with the active site of HIV-1 IN (PDB ID: 1QS4)

\begin{tabular}{ccccccc}
\hline Ligand & $\begin{array}{l}\text { Docking } \\
\text { score }\end{array}$ & H-bond & $\begin{array}{l}\text { Metal } \\
\text { coordination }\end{array}$ & $\begin{array}{c}\text { Pi-Pi } \\
\text { stacking }\end{array}$ & $\begin{array}{l}\text { Pi- } \\
\text { cation }\end{array}$ & $\begin{array}{l}\text { Salt } \\
\text { bridge }\end{array}$ \\
\hline CCL & -7.5 & $\begin{array}{r}\text { ASN 155 } \\
\text { LYS 156 } \\
\text { THR 66 } \\
\text { LYS 159 }\end{array}$ & x & x & x & x \\
ASN 155 \\
ASP 64
\end{tabular}

Table 2. The physiochemical property results of the designed compounds

\begin{tabular}{|c|c|c|c|c|c|c|c|c|}
\hline $\begin{array}{l}\text { Comp. } \\
\text { No }\end{array}$ & $\begin{array}{c}\text { TPSA } \\
\left(\AA^{2}\right)\end{array}$ & $n \mathrm{HD}$ & $\imath \mathrm{HA}$ & $\begin{array}{l}\log \\
P_{\mathrm{o} / \mathrm{w}}\end{array}$ & $\begin{array}{c}\log \\
S\end{array}$ & $\begin{array}{l}\log K p \\
(\mathrm{~cm} / \mathrm{s})\end{array}$ & Lipinski & $\begin{array}{c}\text { Druglikeness } \\
\text { Score }\end{array}$ \\
\hline 1 & 78.43 & 3 & 5 & 4.13 & -5.03 & -5.54 & 0 & 0.24 \\
\hline 2 & 78.43 & 3 & 5 & 4.16 & -4.97 & -5.8 & 0 & 0.25 \\
\hline 3 & 78.43 & 3 & 5 & 4.70 & -5.56 & -5.32 & 1 & 0.31 \\
\hline 4 & 78.43 & 3 & 5 & 5.38 & -6.02 & -4.99 & 1 & 0.35 \\
\hline 5 & 78.43 & 3 & 5 & 4.01 & -5.03 & -5.54 & 0 & 0.11 \\
\hline 6 & 78.43 & 3 & 5 & 4.24 & -4.97 & 5.8 & 0 & 0.49 \\
\hline 7 & 78.43 & 3 & 5 & 4.80 & -5.56 & -5.32 & 1 & 0.58 \\
\hline 8 & 78.43 & 3 & 5 & 5.35 & -6.02 & -4.99 & 1 & 0.63 \\
\hline 9 & 78.43 & 3 & 5 & 3.99 & -5.03 & -5.54 & 0 & 0.60 \\
\hline 10 & 78.43 & 3 & 5 & 4.17 & -4.97 & -5.8 & 0 & 0.54 \\
\hline 11 & 78.43 & 3 & 5 & 4.72 & -5.56 & -5.32 & 1 & 0.66 \\
\hline 12 & 78.43 & 3 & 5 & 5.40 & -6.02 & -4.99 & 1 & 0.72 \\
\hline 13 & 78.43 & 3 & 3 & 4.49 & -5.9 & -4.99 & 0 & 0.42 \\
\hline 14 & 78.43 & 3 & 3 & 4.68 & -5.83 & -5.26 & 0 & 0.46 \\
\hline 15 & 78.43 & 3 & 3 & 5.17 & -6.43 & -4.77 & 1 & 0.50 \\
\hline 16 & 78.43 & 3 & 3 & 5.76 & -6.9 & -4.43 & 1 & 0.53 \\
\hline 17 & 78.43 & 3 & 3 & 4.46 & -5.9 & -4.99 & 0 & 0.18 \\
\hline 18 & 78.43 & 3 & 3 & 4.55 & -5.83 & -5.26 & 0 & 0.58 \\
\hline 19 & 78.43 & 3 & 3 & 5.12 & -6.43 & -4.77 & 1 & 0.66 \\
\hline 20 & 78.43 & 3 & 3 & 5.68 & -6.9 & -4.43 & 1 & 0.71 \\
\hline 21 & 78.43 & 3 & 3 & 4.45 & -5.9 & -4.99 & 0 & 0.77 \\
\hline 22 & 78.43 & 3 & 3 & 4.68 & -5.83 & -5.26 & 0 & 0.71 \\
\hline 23 & 78.43 & 3 & 3 & 5.20 & -6.43 & -4.77 & 1 & 0.81 \\
\hline 24 & 78.43 & 3 & 3 & 5.85 & -6.9 & -4.43 & 1 & 0.86 \\
\hline 25 & 78.43 & 3 & 3 & 4.69 & -6.54 & -5.44 & 2 & 0.16 \\
\hline 26 & 78.43 & 3 & 3 & 4.81 & -6.46 & -5.71 & 2 & 0.19 \\
\hline 27 & 78.43 & 3 & 3 & 5.34 & -7.06 & -5.22 & 2 & 0.25 \\
\hline 28 & 78.43 & 3 & 3 & 5.90 & -7.53 & -4.88 & 2 & 0.25 \\
\hline 29 & 78.43 & 3 & 3 & 4.61 & -6.54 & -5.44 & 2 & -0.02 \\
\hline 30 & 78.43 & 3 & 3 & 4.74 & -6.46 & -5.71 & 2 & 0.39 \\
\hline 31 & 78.43 & 3 & 3 & 5.31 & -7.06 & -5.22 & 2 & 0.47 \\
\hline 32 & 78.43 & 3 & 3 & 5.93 & -7.53 & -4.88 & 2 & 0.52 \\
\hline 33 & 78.43 & 3 & 3 & 4.61 & -6.54 & -5.44 & 2 & 0.46 \\
\hline 34 & 78.43 & 3 & 3 & 4.78 & -6.46 & -5.71 & 2 & 0.42 \\
\hline 35 & 78.43 & 3 & 3 & 5.41 & -7.06 & -5.22 & 2 & 0.53 \\
\hline 36 & 78.43 & 3 & 3 & 5.94 & -7.53 & -4.88 & 2 & 0.59 \\
\hline 37 & 96.89 & 3 & 5 & 3.57 & -5.21 & -5.48 & 0 & -0.18 \\
\hline 38 & 96.89 & 3 & 5 & 3.50 & -4.79 & -6.13 & 0 & 0.12 \\
\hline 39 & 96.89 & 3 & 5 & 4.16 & -5.39 & -5.65 & 0 & 0.20 \\
\hline 40 & 96.89 & 3 & 5 & 4.70 & -5.86 & -5.31 & 0 & 0.25 \\
\hline 41 & 96.89 & 3 & 5 & 3.38 & -4.86 & -5.87 & 0 & -0.04 \\
\hline 42 & 96.89 & 3 & 5 & 3.50 & -4.79 & -6.13 & 0 & 0.39 \\
\hline 43 & 96.89 & 3 & 5 & 4.17 & -5.39 & -5.65 & 0 & 0.54 \\
\hline 44 & 96.89 & 3 & 5 & 4.72 & -5.86 & -5.31 & 0 & 0.60 \\
\hline 45 & 96.89 & 3 & 5 & 3.41 & -4.86 & -5.87 & 0 & 0.30 \\
\hline 46 & 96.89 & 3 & 5 & 3.52 & -4.79 & -6.13 & 0 & 0.32 \\
\hline 47 & 96.89 & 3 & 5 & 4.17 & -5.39 & -5.65 & 0 & 0.48 \\
\hline 48 & 96.89 & 3 & 5 & 4.72 & -5.86 & -5.31 & 0 & 0.55 \\
\hline
\end{tabular}

Comp.: Compound

\subsection{ADME Prediction}

The ADME predictions of the designed compounds were performed by SwissADME database, and 
physiochemical properties; hydrogen bond acceptors $(n \mathrm{HA})$, hydrogen bond donors $(n \mathrm{HD})$, and topological polar surface area (TPSA). Besides, lipophilicity (iLOGP, XLOGP3, WLOGP, MLOGP, SILICOS-IT, and Consensus $P_{0 / \mathrm{w}}$ ), water-solubility properties (ESOL, Ali, SILICOS-IT), and drug-likeness factors (Lipinski's Rules, Ghose, Veber, Egan, Muegge) were also calculated. All designed compounds showed high topological polar surface area (TPSA) ranging from $78.43 \AA^{2}$ to $96.89 \AA^{2}$. The methoxy-containing compounds were found to be higher than the others. $n \mathrm{HD}$ of the compounds was found 3 , whereas $n$ HA of compounds was between 3 and 5 . The calculated lipophilicity properties were given in the consensus model ( $n$-octanol and water: $\log P_{\mathrm{o} / \mathrm{w}}$ ) which was ranging from 3.41 to 5.94 . When the water solubility properties were examined, all compounds were found to be moderately or poorly soluble with the Log $S$ values ranging from -4.79 to $-7.53 \mathrm{mg} / \mathrm{mL}$. Pharmacokinetic properties such as GI absorption, BBB permeant, P-gp substrate, and skin permeation ( $\log K \mathrm{p})$ were also calculated, and the designed compounds exhibited high Gastrointestinal absorption (GI), while none of them showed blood-brain barrier permeant. Skin permeation kinetics $(\log K \mathrm{p})$ of them were found to be $4.43-6.13 \mathrm{~cm} / \mathrm{s}$ (Table 2).

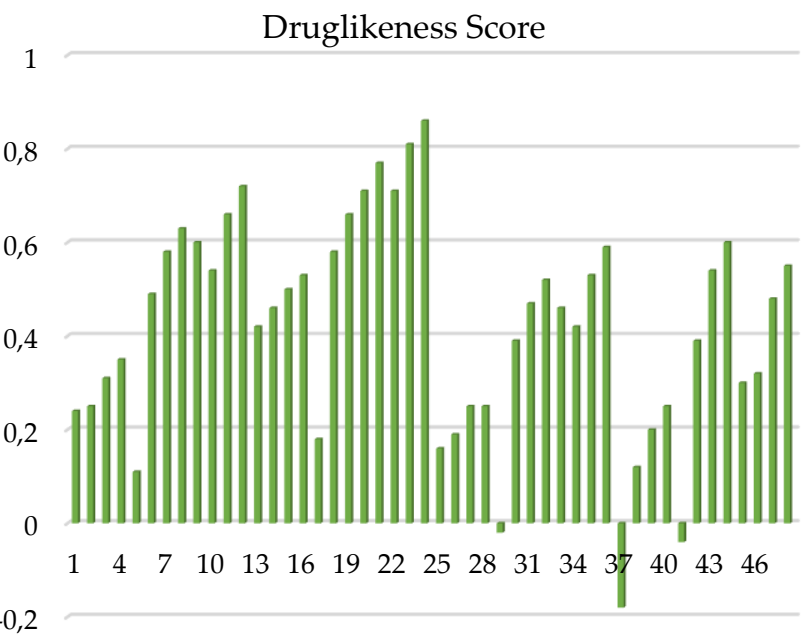

Figure 3. Drug-likeness score of the designed compounds

The Lipinski rule of five is an important parameter for drug-likeness factors of the compounds, and it has to be $\leq 1$. Among the 48 designed compounds, compounds 25-36 containing bromophenyl as a hydrophobic moiety did not obey this rule, and for this reason, these compounds were eliminated. Drug-likeness scores was specified via the Molsoft database (www.molsoft.com). Although all compounds showed drug-likeness score with varying values, among them, compounds 12, 21-24 displayed the highest values with $0.72,0.77,0.71,0.81$, and 0.86 , respectively.
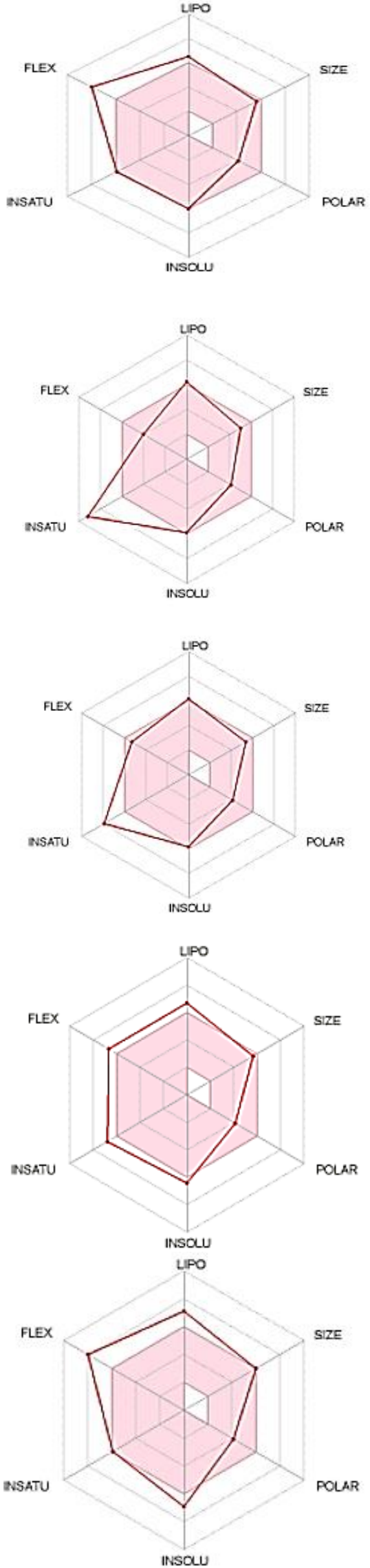

Figure 4. The Bioavailability Radar enables at first glance at the druglikeness of the compounds 


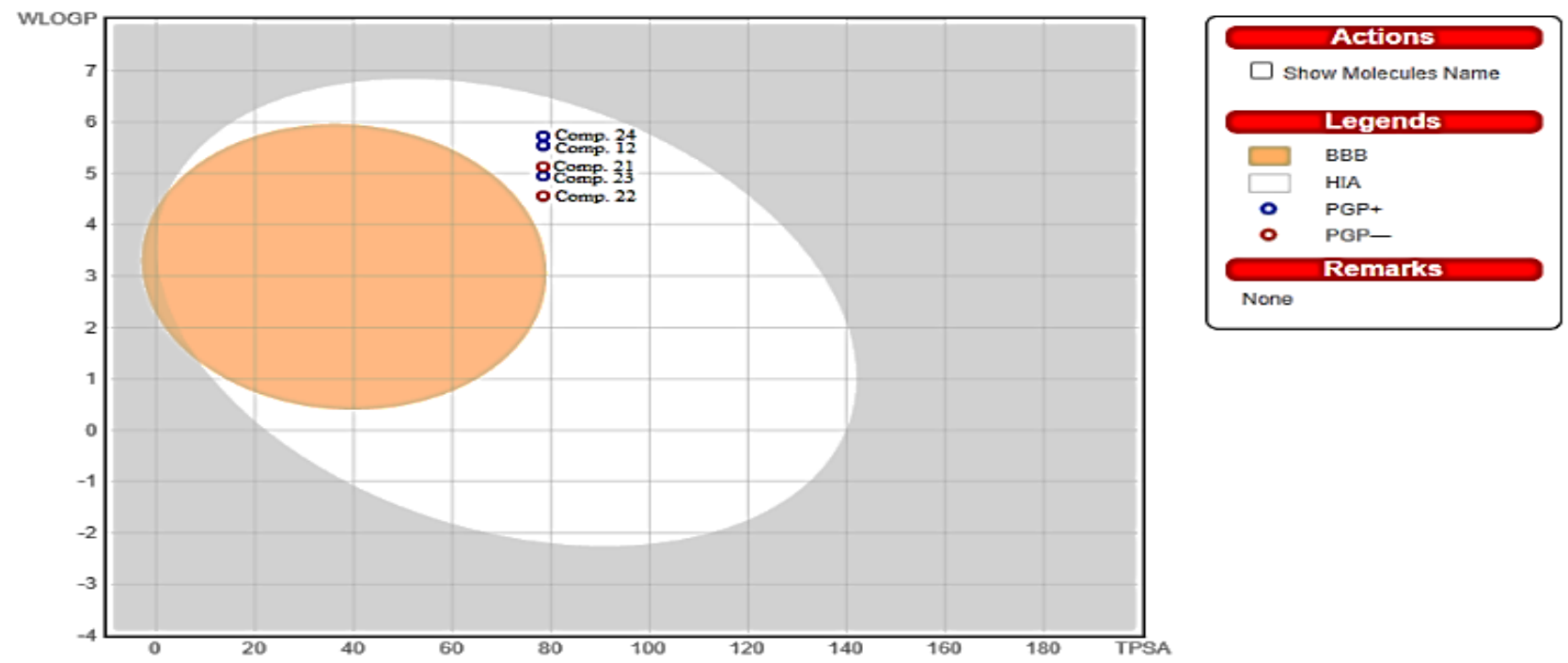

Figure 5. BOILED-Egg presentation of the compounds

Compared to methoxy-containing compounds which showed the highest TPSA results with 96.89, these five compounds exhibited a 1-6-fold better drug-likeness score than them (All SwissADME results were given in detail in Fig. 3). Moreover, the bioavailability score of these compounds was found to be 0.55 (Fig. 4). For further in silico analysis, the above compounds were chosen as hit compounds.

In Fig. 4, the pink area describes the optimal range for each property (lipophilicity: XLOGP3 between -0.7 and +5.0, size: $\mathrm{MW}$ between 150 and $500 \mathrm{~g} / \mathrm{mol}$, polarity: TPSA between 20 and $130 \AA^{2}$, solubility: $\log S$ not higher than 6, saturation: fraction of carbons in the $\mathrm{sp}^{3}$ hybridization not less than 0.25 , and flexibility: no more than 9 rotatable bonds.

Furthermore, the BOILED-Egg profile which lets for intuitive consideration of passive gastrointestinal absorption (HIA) and brain penetration (BBB) in the function of the position of the molecules in the WLOGPvs-TPSA referential was screened for the selected five compounds [25]. The white area is for the high probability of passive absorption by the gastrointestinal tract, while the yellow area is for the high probability of brain penetration. Also, the marks are colored in blue if predicted as actively effluxed by $\mathrm{P}-\mathrm{gp}(\mathrm{PGP}+)$ and in red if estimated as non-substrate of P-gp (PGP-). It was concluded that all our compounds were estimated wellabsorbed but not accessing the brain, and compounds 12, 23, and 24 were subject to active efflux (blue dot), whereas compounds 21 and 22 were not subject to active efflux (red dot) (Fig. 5).

\subsection{Target Prediction}

The target estimation of the chosen compounds was examined using the SwissTargetPrediction platform with the following investigations 15 of the outcomes depicted as a pie-chart (Fig. 6). The compound 12 containing $p$-fluorophenyl as a hydrophobic aromatic unit and $n=3$ as a linker was predicted as $26.7 \%$ of Family AG protein-coupled receptor, $20 \%$ of both enzyme and kinase, while compound 21 comprising $p$ chlorophenyl as a hydrophobic aromatic unit and $\mathrm{n}=0$ was predicted as $33.3 \%$ of protease and $26.7 \%$ of the kinase. Compounds 22 and 23 were estimated as Family AG protein coupled-receptor with $40.0 \%$ and $46.7 \%$, respectively, whereas compound 24 including $p$ chlorophenyl as a hydrophobic aromatic unit and $n=3$ was predicted as $46.7 \%$ of Family AG protein coupledreceptor and $20 \%$ of the enzyme. One of the compound's result tables comprising of Common Name, Uniprot ID, Target, ChEMBL-ID, Probability, Target Class, and Known actives in 2D/3D are given in the Supporting Information file.

\subsection{Toxicity Prediction}

Toxicity predictions were screened and all compounds, except for 22, do not have any AMES toxicity, while all compounds, except for 12, produce hepatotoxicity. Moreover, all compounds were not found to be cause skin sensitivity. Although they were also predicted as hEGR II inhibitors, none of them showed any hEGR I inhibition results. It was estimated maximum tolerated dose for humans which was ranging from $0.426 \mathrm{log}$ $\mathrm{mg} / \mathrm{kg} /$ day to $0.79 \log \mathrm{mg} / \mathrm{kg} /$ day. Compound 12 exhibited the lowest both oral rat acute toxicity with a $\mathrm{LD}_{50}$ value of $2.271 \mathrm{~mol} / \mathrm{kg}$ and chronic oral rat toxicity with $1.497 \mathrm{log}$ mg/kg_bw/day. 0.397 - $0.672 \mathrm{log} \mathrm{mg} / \mathrm{L}$

induced T. Pyriformis toxicity and $-0.765-0.027 \log \mathrm{mM}$ induced Minnow toxicity were found for the compounds (Table 3). 


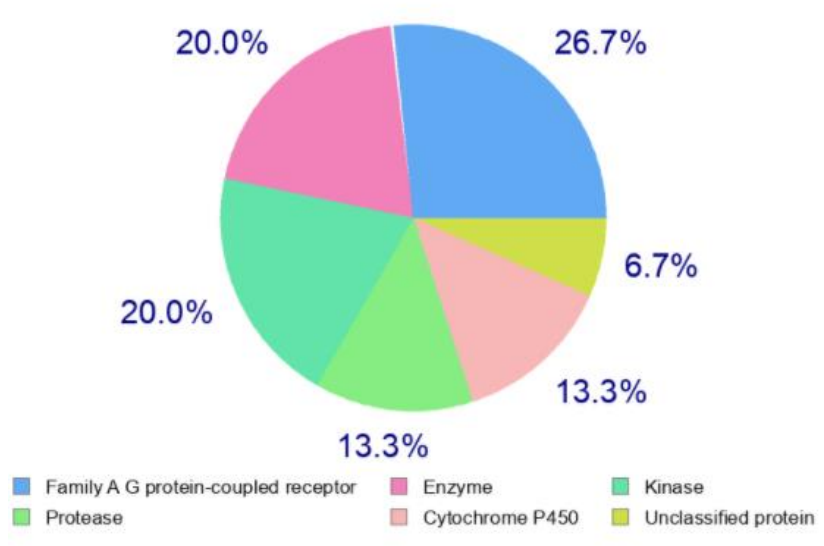

Compound 12

$40.0 \%$

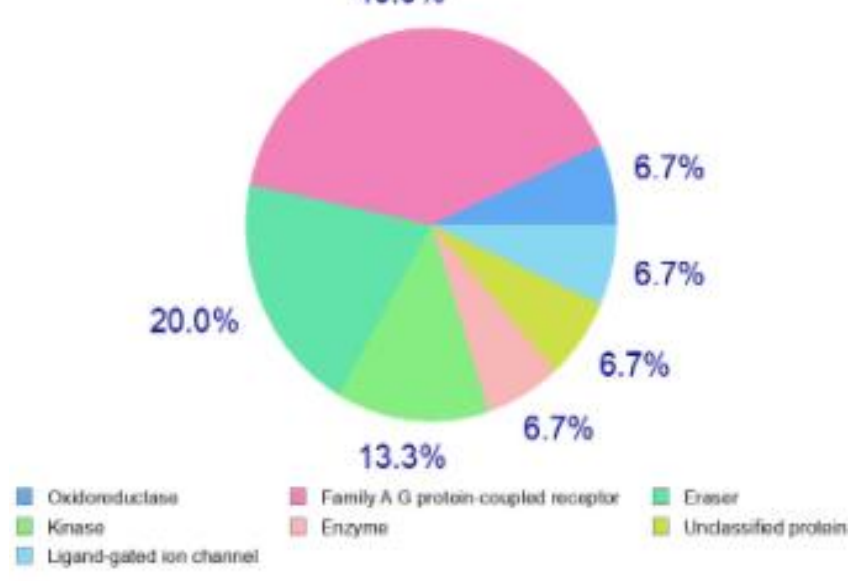

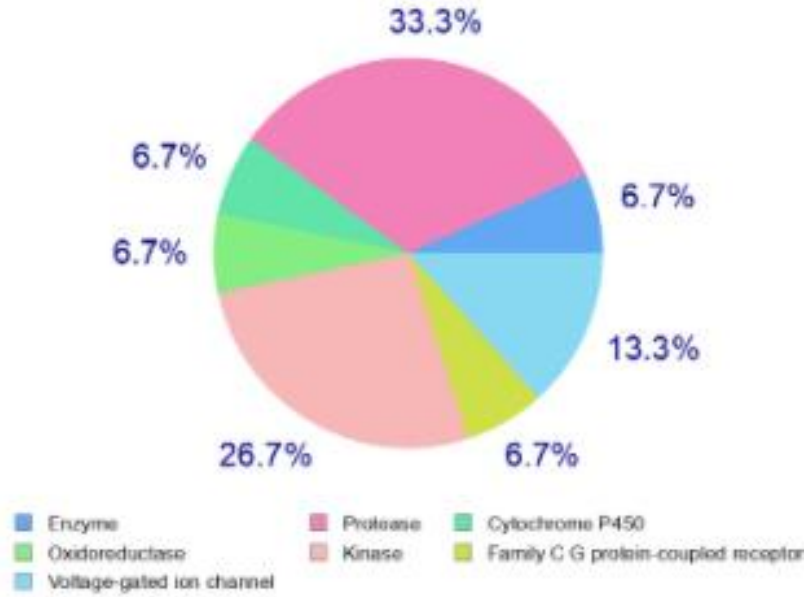

Voltage-gated ion chamed

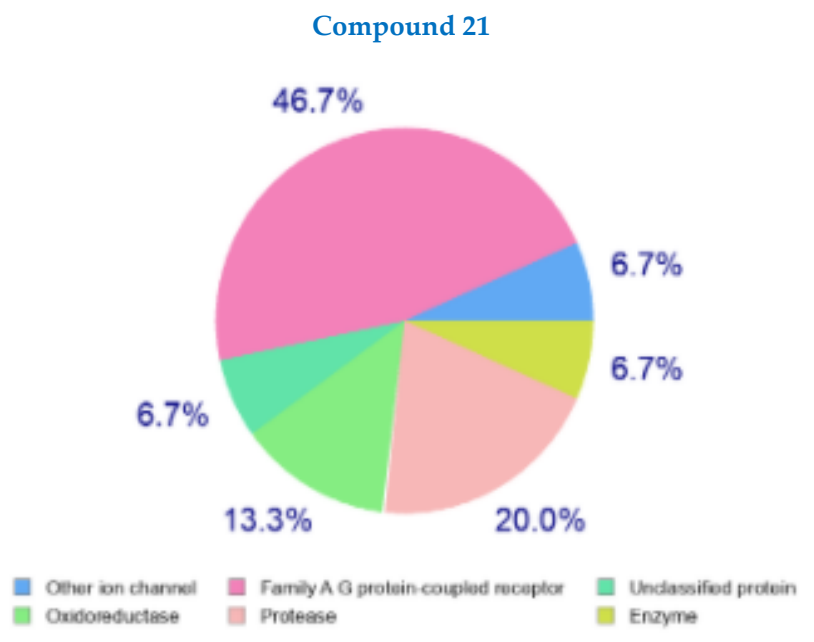

Compound 23

Compound 22
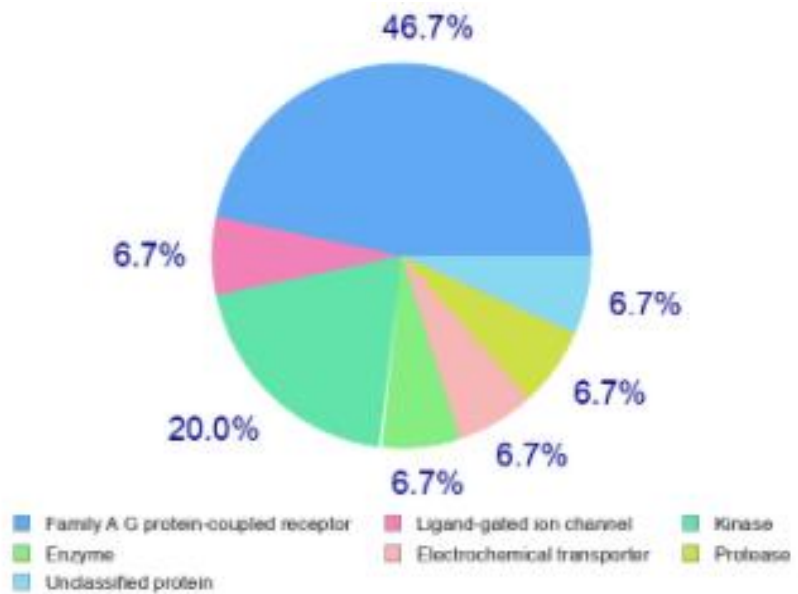

Compound 24

Figure 6. SwissTargetPrediction of the chosen compounds

Table 3. Toxicity prediction results of the selected compounds

\begin{tabular}{cccccccccc}
\hline $\begin{array}{c}\text { Comp. } \\
\text { No }\end{array}$ & $\begin{array}{c}\text { AMES } \\
\text { Toxicity }\end{array}$ & $\begin{array}{c}\text { Maximum } \\
\text { Tolerated } \\
\text { Dose }\end{array}$ & $\begin{array}{c}\text { hEGR I } \\
\text { inhibitor }\end{array}$ & $\begin{array}{c}\text { hEGR II } \\
\text { inhibitor }\end{array}$ & $\begin{array}{c}\text { Oral Rat Acute } \\
\text { Toxicity (LD) }\end{array}$ & $\begin{array}{c}\text { Chronic Oral } \\
\text { Rat Toxicity } \\
\text { (LOAEL) }\end{array}$ & Hepatotoxicity & $\begin{array}{c}\text { Skin } \\
\text { Sensitisation }\end{array}$ & $\begin{array}{c}\text { T.Pyriformis Minnow } \\
\text { Toxicity } \\
\text { Toxicity }\end{array}$ \\
\hline $\mathbf{1 2}$ & No & 0.457 & No & Yes & 2.271 & 1.497 & No & No & 0.397 \\
$\mathbf{2 1}$ & No & 0.426 & No & Yes & 2.462 & 1.757 & Yes & No & 0.464 \\
$\mathbf{2 2}$ & Yes & 0.790 & No & Yes & 2.395 & 1.536 & Yes & No & 0.470 \\
$\mathbf{2 3}$ & No & 0.581 & No & Yes & 2.455 & 1.005 & -0.765 \\
$\mathbf{2 4}$ & No & 0.520 & No & Yes & 2.414 & 1.740 & Yes & No & 0.672 \\
\hline
\end{tabular}

Comp.: Compound 


\section{Conclusion}

In the present study, we have investigated the novel potential compounds against HIV-1 IN with the in silico studies. We designed 48 novel compounds with various functional groups such as $-\mathrm{F}, \mathrm{Cl},-\mathrm{Br},-\mathrm{OCH} 3$ in the phenyl ring which is the hydrophobic site, and we added to the structure linker which is the alkyl chain between amide bond and hydrophobic part. It was observed that the presence of carbonyl and hydroxyl group in the compound was very significant for the binding of the active site of the enzyme. Also, it can be concluded from the SwissADME and toxicity results that the alkyl chain length was also important for both solubility and druglikeness. It was determined that the solubility decreases as the alkyl chain length increases in the compounds, on the contrary, it was found that there is an increase in the drug-likeness score as the alkyl number increases. We also considered the position of the substituent in the phenyl ring for the activity when designing the compounds, and it was clearly seen that the substituent in the p-position was more important than the other positions. The bromine compounds were found to be more potential for activity, whereas methoxy-containing compounds had less potential. For the best compound, we performed molecular docking studies and hydrogen bonding interactions between ligands and ASN155, ASP 64 amino acids of the receptor exhibited significance for potent HIV-1 IN. Considering the overall results, the five compounds and especially compound 24 can be a potent inhibitor against HIV-1 IN.

\section{Declaration of Competing Interest}

The author declares that he has no known competing financial interests or personal relationships that could have appeared to influence the work reported in this paper.

\section{Acknowledgments}

I am very grateful to Efe Doğukan Dinçel from İstanbul University, Department of Pharmacy for molecular docking studies.

\section{References}

[1] O. Delelis, K. Carayon, A. Saib, E. Deprez, J.F. Mouscadet, Integrase and integration: biochemical activities of HIV-1 integrase, Retrovirology 5, 2008, 114-127.

[2] N. Neamati, Z. Lin, R.G. Karki, A. Orr, K. Cowansage, D Strumberg, Metal-dependent inhibition of HIV-1 integrase, J Med Chem, 45, 2002, 5661-5670.

[3] T. Kawasuji, T. Yoshinaga, A. Sato, M. Yodo, T. Fujiwara, R. Kiyama, A platform for designing HIV integrase inhibitors. Part 1: 2-hydroxy-3-heteroaryl acrylic acid derivatives as novel HIV integrase inhibitor and modeling of hydrophilic and hydrophobic pharmacophores, Bioorgan Med Chem, 14, 2006, 8430-8445.

[4] B.A. Johns, A.C. Svolto, Advances in two-metal chelation inhibitors of HIV integrase, Expert Opin Ther Pat, 18, 2008, 12251237.

[5] M. Rowley, The discovery of raltegravir, an integrase inhibitor for the treatment of HIV infection, Prog Med Chem, 46, 2008, 1-28.

[6] M. Sato, H. Kawakami, T. Motomura, H. Aramaki, T. Matsuda, M. Yamashita, Quinolone carboxylic acids as a novel monoketo acid class of human immunodeficiency virus type 1 integrase inhibitors, J Med Chem, 52, 2009, 4869-4882.

[7] C. Katlama, R. Murphy, Dolutegravir for the treatment of HIV Expert Opin Inv Drug, 21, 2008, 523-530.

[8] R. Di Santo, Inhibiting the HIV integration process: past, present, and the future, J Med Chem, 57, 2014, 539-566.

[9] C. Liao, C. Marchand, T.R. Burke, Y. Pommier, M.C. Nicklaus, Authentic HIV-1 integrase inhibitors, Future Med Chem, 2, 2010 , 1107-1122.

[10] H. Sirous, G. Chemi, S. Gemma, S. Butini, Z. Debyser, F. Christ, L. Saghaie, S. Brogi, A. Fassihi, G. Campiani, M. Brindisi, Identification of novel 3-hydroxy-pyran-4-one derivatives as potent HIV-1 integrase inhibitors using in silico structure-based combinatorial library design approach, Front Chem, 7, 2019, 1-20.

[11] M. Hay, D.W. Tomas, J.L. Craighead, C. Economides, J. Rosenthal, Clinical development success rates for investigational drugs, Nat Biotechnol, 32, 2014, 40-51.

[12] J.L. Dahlin, J. Inglese, M.A. Walters, Mitigating risk in academic preclinical drug discovery, Nature Rev Drug Discov, 14, 2015, 279-294.

[13] D.E.V. Pires, T.L. Blundell, D.B. Ascher, pkCSM: Predicting smallmolecule pharmacokinetic and toxicity properties usin graphbased signatures, J Med Chem, 58, 2015, 4066-4072.

[14] F. Cheng, W. Li, Y. Zhou, J. Shen, Z. Wu, G. Liu, P.W. Lee, Y. Tang, admetSAR: a comprehensive source and free tool for assessment of chemical ADMET properties, J Chem Inf Model, 52, 2012, 30993105.

[15] A. Daina, O. Michielin, V. Zoete, iLOGP: A simple, robust, and efcient description of $\mathrm{n}$-octanol/water partition coefcient for drug design using the GB/SA approach, J Chem Inf Model, 54, 2014, 3284-3301.

[16] L. Di, P. Artursson, A. Avdeef, G.F. Ecker, B. Faller, H. Fischer, J.B. Houston, M. Kansy, E.H. Kerns, S.D. Krämer, H. Lennernäs, K. Sugano, Evidence-based approach to assess passive diffusion and carrier-mediated drug transport, Drug Discov Today, 17, 2012, 905-912.

[17] V. Zoete, A. Daina, C. Bovigny, O. Michielin, SwissSimilarity: A web tool for low to ultra high troughput ligand-based virtual screening, J Chem Inf Model, 56, 2016, 1399-1404.

[18] D. Gfeller, SwissTargetPrediction: a web server for target prediction of bioactive small molecules, Nucleic Acids Res, 42, 2014, W32-W38.

[19] A. Grosdidier, V. Zoete, O. Michielin, SwissDock, a protein-small molecule docking web service based on EADock DSS, Nucleic Acids Res, 39, 2011, W270-W277.

[20] M. Wirth, V. Zoete, O. Michielin, W.H.B. Sauer, SwissBioisostere: a database of molecular replacements for ligand design, Nucleic Acids Res, 41, 2013, D1137-D1143.

[21] V. Zoete, M.A. Cuendet, A. Grosdidier, O. Michielin, SwissParam: a fast force feld generation tool for small organic molecules, J Comput Chem, 32, 2011, 2359-2368.

[22] A. Daina, O. Michielin, V. Zoete, SwissADME: A free web tool to evaluate pharmacokinetics, drug-likeness and medicinal chemistry friendliness of small molecules, Sci Rep, 7, 2017, 42717.

[23] M.J. Keiser, B.L. Roth, B.N. Armbruster, P. Ernsberger, J.J. Irwin, B.K. Shoichet, Relating protein pharmacology by ligand chemistry, Nat Biotechnol, 25, 2007, 197-206. 
[24] D.E. Pires, T.L. Blundell, D.B. Ascher, PkCSM: Predicting smallmolecule pharmacokinetic and toxicity properties using graphbased signatures, J Med Chem, 58, 2015, 4066-4072.

[25] A. Daina, V. Zoete, A BOILED-Egg to predict gastrointestinal absorption and brain penetration of small molecules, ChemMedChem, 11, 2016, 1117-1121.

[26] P. Selvam, M. Chandramohan, E. De Clercq, C. Pannecouque, M. Witrouw, Synthesis and anti-HIV activity of 4-[(1,2-dihydro-2oxo-3H-indol-3-ylidene)amino]-N-(4,6-dimethyl-2-pyrimidinyl)benzene sulphonamide and its derivatives, Eur J Pharm Sci, 14, 2001, 313-316.

[27] G.M. Sastry, M. Adzhigirey, T. Day, R. Annabhimoju, W. Sherman, Protein and ligand preparation: parameters, protocols, and influence on virtual screening enrichments, J Comput Aided Mol Des, 27, 2013, 221-234.

[28] R.A. Friesner, J.L. Banks, R.B. Murphy, T.A. Halgren, J.J. Klicic, D.T. Mainz, M.P. Repasky, E.H. Knoll, M. Shelley, J.K. Perry, Glide: a new approach for rapid, accurate docking and scoring. 1. Method and assessment of docking accuracy, J Med Chem, 47, 2004, 1739-1749.

[29] R.A. Friesner, R.B. Murphy, M.P. Repasky, L.L. Frye, J.R. Greenwood, T. Halgren, P.C. Sanschagrin, D.T. Mainz, Extra precision glide: Docking and scoring incorporating a model of hydrophobic enclosure for protein- ligand complexes, J Med Chem, 49, 2006, 6177-6196.

[30] T.A. Halgren, R.B. Murphy, R.A. Friesner, H.S. Beard, L.L. Frye, W.T. Pollard, J.L. Banks, Glide: a new approach for rapid, accurate docking and scoring. 2. Enrichment factors in database screening, J Med Chem, 47, 2004, 1750-1759.

[31] B. Debnath, S. Ganguly, Synthesis, biological evaluation, in silico docking, and virtual ADME studies of 2-[2-Oxo-3-(arylimino) indolin-1-yl]-N-arylacetamides as potent anti-breast cancer agents, Monatsh Chem, 147, 2016, 565-574. 


\section{Supporting information}

\section{SwissTargetPrediction}

\begin{tabular}{|c|c|c|c|c|c|c|}
\hline Target & $\begin{array}{l}\text { Common } \\
\text { name }\end{array}$ & $\begin{array}{l}\text { Uniprot } \\
\text { ID }\end{array}$ & ChEMBL ID & Target Class & Probability* & $\begin{array}{l}\text { Known } \\
\text { actives } \\
\text { (3D/2D) }\end{array}$ \\
\hline $\begin{array}{l}\text { Dopamine D2 receptor } \\
\text { (by homology) }\end{array}$ & DRD2 & P14416 & CHEMBL217 & $\begin{array}{l}\text { Family A G } \\
\text { protein-coupled } \\
\text { receptor }\end{array}$ & 0.120225750913 & $0 / 405$ \\
\hline $\begin{array}{l}\text { Serotonin } 2 \mathrm{a}(5-\mathrm{HT} 2 \mathrm{a}) \\
\text { receptor (by } \\
\text { homology) }\end{array}$ & HTR2A & P28223 & CHEMBL224 & $\begin{array}{l}\text { Family A G } \\
\text { protein-coupled } \\
\text { receptor }\end{array}$ & 0.120225750913 & $0 / 140$ \\
\hline $\begin{array}{l}\text { 11-beta-hydroxysteroid } \\
\text { dehydrogenase } 1\end{array}$ & HSD11B1 & P28845 & CHEMBL4235 & Enzyme & 0.120225750913 & $0 / 150$ \\
\hline MAP kinase p38 alpha & MAPK14 & Q16539 & CHEMBL260 & Kinase & 0.120225750913 & $0 / 37$ \\
\hline $\begin{array}{l}\text { Serine/threonine- } \\
\text { protein kinase Chk1 }\end{array}$ & CHEK1 & 014757 & CHEMBL4630 & Kinase & 0.120225750913 & $1 / 0$ \\
\hline $\begin{array}{l}\text { Serine/threonine- } \\
\text { protein kinase WEE1 }\end{array}$ & WEE1 & P30291 & CHEMBL5491 & Kinase & 0.120225750913 & $4 / 0$ \\
\hline Trypsin I & PRSS1 & P07477 & CHEMBL209 & Protease & 0.120225750913 & $0 / 28$ \\
\hline Epoxide hydratase & EPHX2 & P34913 & CHEMBL2409 & Protease & 0.120225750913 & $0 / 57$ \\
\hline $\begin{array}{l}\text { Poly [ADP-ribose] } \\
\text { polymerase-1 }\end{array}$ & PARP1 & P09874 & CHEMBL3105 & Enzyme & 0.120225750913 & $0 / 84$ \\
\hline Cytochrome P450 2C9 & CYP2C9 & P11712 & CHEMBL3397 & $\begin{array}{l}\text { Cytochrome } \\
\text { P450 }\end{array}$ & 0.120225750913 & $0 / 7$ \\
\hline Cytochrome P450 2C19 & CYP2C19 & P33261 & CHEMBL3622 & $\begin{array}{l}\text { Cytochrome } \\
\text { P450 }\end{array}$ & 0.120225750913 & $0 / 7$ \\
\hline $\begin{array}{l}\text { Poly [ADP-ribose] } \\
\text { polymerase } 2\end{array}$ & PARP2 & Q9UGN5 & CHEMBL5366 & Enzyme & 0.120225750913 & $0 / 22$ \\
\hline $\begin{array}{l}\text { Calcitonin gene-related } \\
\text { peptide } 1\end{array}$ & CALCA & P06881 & CHEMBL5293 & $\begin{array}{l}\text { Unclassified } \\
\text { protein }\end{array}$ & 0.120225750913 & $6 / 0$ \\
\hline $\begin{array}{l}\text { C-C chemokine receptor } \\
\text { type } 4\end{array}$ & CCR4 & P51679 & CHEMBL2414 & $\begin{array}{l}\text { Family A G } \\
\text { protein-coupled } \\
\text { receptor }\end{array}$ & 0.0 & $2 / 0$ \\
\hline Interleukin-8 receptor A & CXCR1 & P25024 & CHEMBL4029 & $\begin{array}{l}\text { Family A G } \\
\text { protein-coupled } \\
\text { receptor }\end{array}$ & 0.0 & $12 / 0$ \\
\hline $\begin{array}{l}\text { C-C chemokine receptor } \\
\text { type } 6\end{array}$ & CCR6 & P51684 & CHEMBL4423 & $\begin{array}{l}\text { Family A G } \\
\text { protein-coupled } \\
\text { receptor }\end{array}$ & 0.0 & $2 / 0$ \\
\hline $\begin{array}{l}\text { CCR4-NOT transcription } \\
\text { complex subunit } 7\end{array}$ & CNOT7 & Q9UIV1 & CHEMBL3616361 & Hydrolase & 0.0 & $1 / 0$ \\
\hline Glycine transporter 2 & SLC6A5 & Q9Y345 & CHEMBL3060 & $\begin{array}{l}\text { Electrochemical } \\
\text { transporter }\end{array}$ & 0.0 & $0 / 41$ \\
\hline Mu opioid receptor & OPRM1 & P35372 & CHEMBL233 & $\begin{array}{l}\text { Family A G } \\
\text { protein-coupled } \\
\text { receptor }\end{array}$ & 0.0 & $0 / 411$ \\
\hline Kappa Opioid receptor & OPRK1 & P41145 & CHEMBL237 & $\begin{array}{l}\text { Family A G } \\
\text { protein-coupled } \\
\text { receptor }\end{array}$ & 0.0 & $0 / 219$ \\
\hline $\begin{array}{l}\text { Delta opioid receptor } \\
\text { (by homology) }\end{array}$ & OPRD1 & P41143 & CHEMBL236 & $\begin{array}{l}\text { Family A G } \\
\text { protein-coupled } \\
\text { receptor }\end{array}$ & 0.0 & $0 / 349$ \\
\hline Plasminogen & PLG & P00747 & CHEMBL1801 & Protease & 0.0 & $0 / 3$ \\
\hline $\begin{array}{l}\text { C-C chemokine receptor } \\
\text { type } 3\end{array}$ & CCR3 & P51677 & CHEMBL3473 & $\begin{array}{l}\text { Family A G } \\
\text { protein-coupled }\end{array}$ & 0.0 & $0 / 21$ \\
\hline
\end{tabular}

SI-1. Target Prediction results of the compound 12 
<smiles>Cc1cc(C(=O)Nc2ccccc2F)c(O)c(C(=O)Nc2ccccc2F)c1</smiles>

Compound 1<smiles>Cc1cc(C(=O)NCc2ccccc2F)c(O)c(C(=O)NCc2ccccc2F)c1</smiles>

Compound 2<smiles>CC(C)(C)C(=O)NCCc1ccccc1F</smiles><smiles>Cc1cc(C(=O)NCCCc2ccccc2F)c(O)c(C(=O)NCCCc2ccccc2F)c1</smiles>
Compound 4<smiles>Cc1cc(C(=O)Nc2cccc(F)c2)c(O)c(C(=O)Nc2cccc(F)c2)c1</smiles>

Compound 5<smiles>Cc1cc(C(=O)NCc2cccc(F)c2)c(O)c(C(=O)NCc2cccc(F)c2)c1</smiles>

Compound 6<smiles>Cc1cc(C(=O)NCCc2cccc(F)c2)c(O)c(C(=O)NCCc2cccc(F)c2)c1</smiles>

Compound 7

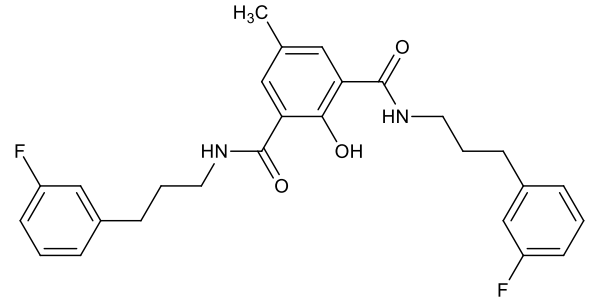

Compound 8<smiles>Cc1cc(C(=O)Nc2ccc(F)cc2)c(O)c(C(=O)Nc2ccc(F)cc2)c1</smiles>

Compound 9<smiles>Cc1cc(C(=O)NCc2ccc(F)cc2)c(O)c(C(=O)NCc2ccc(F)cc2)c1</smiles>

Compound 10<smiles>Cc1cc(C(=O)NCCc2ccc(F)cc2)c(O)c(C(=O)NCCc2ccc(F)cc2)c1</smiles>

Compound 11

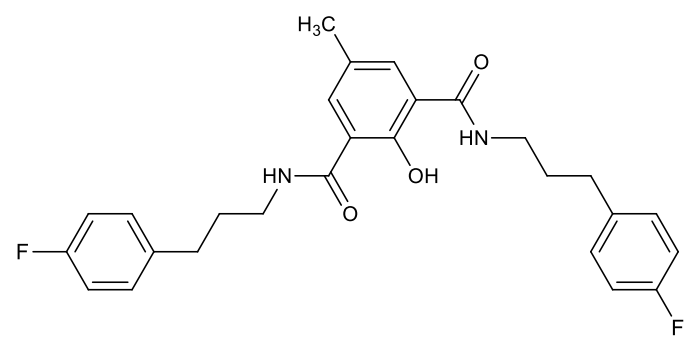

Compound 12<smiles>Cc1cc(C(=O)Nc2ccccc2Cl)c(O)c(C(=O)Nc2ccccc2Cl)c1</smiles>

Compound 13 
<smiles>Cc1cc(C(=O)NCc2ccccc2Cl)c(O)c(C(=O)NCc2ccccc2Cl)c1</smiles>

Compound 14<smiles>CC(=O)OC(C)(C)C(=O)NCCc1ccccc1Cl</smiles><smiles>Cc1cc(C(=O)NCCCc2ccccc2Cl)c(O)c(C(=O)NCCCc2ccccc2Cl)c1</smiles>

Compound 16<smiles>Cc1cc(C(=O)Nc2cccc(Cl)c2)c(O)c(C(=O)Nc2cccc(Cl)c2)c1</smiles>

Compound 17<smiles>CC(C)(C)C(C)(C)C</smiles><smiles>Cc1cc(C(=O)NCCc2cccc(Cl)c2)c(O)c(C(=O)NCCc2cccc(Cl)c2)c1</smiles>

Compound 19

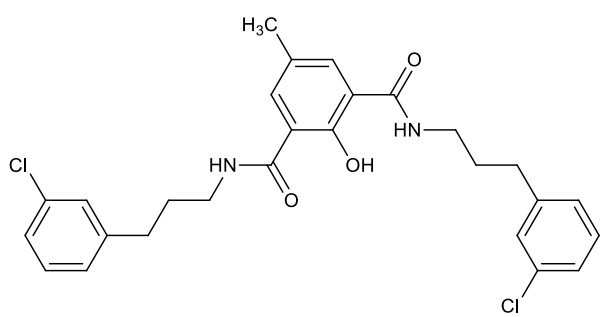

Compound 20<smiles>Cc1cc(C(=O)Nc2ccc(Cl)cc2)c(O)c(C(=O)Nc2ccc(Cl)cc2)c1</smiles>

Compound 21<smiles>Cc1cc(C(=O)NCc2ccc(Cl)cc2)c(O)c(C(=O)NCc2ccc(Cl)cc2)c1</smiles>

Compound 22<smiles>Cc1cc(C(=O)NCCc2ccc(Cl)cc2)c(O)c(C(=O)NCCc2ccc(Cl)cc2)c1</smiles><smiles>Cc1cc(C(=O)NCCCc2ccc(Cl)cc2)c(O)c(C(=O)NCCCc2ccc(Cl)cc2)c1</smiles>

Compound 24<smiles>Cc1cc(C(=O)Nc2ccccc2Br)c(O)c(C(=O)Nc2ccccc2Br)c1</smiles>

Compound 25<smiles>Cc1cc(C(=O)NCc2ccccc2Br)c(O)c(C(=O)NCc2ccccc2Br)c1</smiles>

Compound 26 


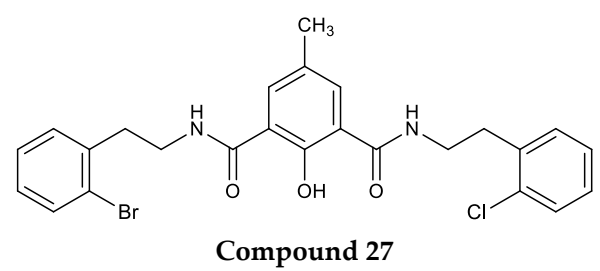<smiles>Cc1cc(C(=O)NCc2ccc(Br)cc2)c(O)c(C(=O)NCc2ccc(Br)cc2)c1</smiles>

Compound 34<smiles>Cc1cc(C(=O)NCCc2ccc(Br)cc2)c(O)c(C(=O)NCCc2ccc(Br)cc2)c1</smiles>

Compound 35

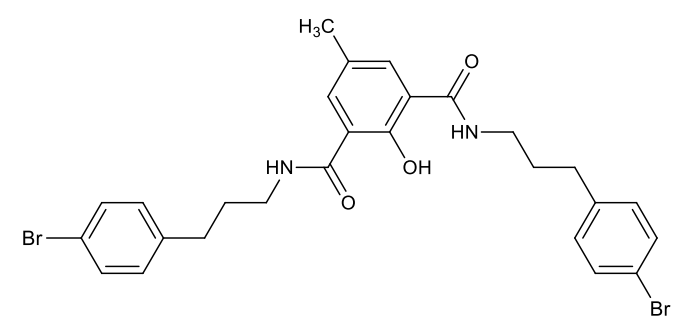

Compound 36<smiles>COc1ccccc1NC(=O)c1cc(C)cc(C(=O)Nc2ccccc2OC)c1O</smiles>

Compound 37<smiles>COc1ccccc1CNC(=O)c1cc(C)cc(C(=O)NCc2ccccc2OC)c1O</smiles>

Compound 38<smiles>COc1ccccc1CCNC(=O)c1cc(C)cc(C(=O)NCCc2ccccc2OC)c1O</smiles>

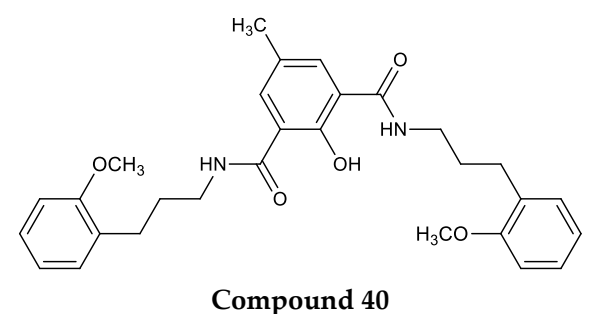<smiles>Cc1cc(C(=O)Nc2ccc(Br)cc2)c(O)c(C(=O)Nc2ccc(Br)cc2)c1</smiles>

Compound 33 
<smiles>COc1cccc(NC(=O)c2cc(C)cc(C(=O)Nc3cccc(OC)c3)c2O)c1</smiles>

Compound 41<smiles>COc1cccc(CNC(=O)c2cc(C)cc(C(=O)NCc3cccc(OC)c3)c2O)c1</smiles><smiles>COc1cccc(CCNC(=O)c2cc(C)cc(C(=O)NCCc3cccc(OC)c3)c2O)c1</smiles>

Compound 43

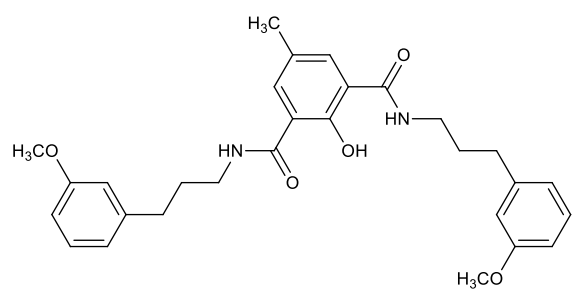

Compound 44<smiles>COc1ccc(NC(=O)c2cc(C)cc(C(=O)Nc3ccc(OC)cc3)c2O)cc1</smiles>

Compound 45<smiles>COc1ccc(CNC(=O)c2cc(C)cc(C(=O)NCc3ccc(OC)cc3)c2O)cc1</smiles>

Compound 46<smiles>COc1ccc(CCNC(=O)c2cc(C)cc(C(=O)NCCc3ccc(OC)cc3)c2O)cc1</smiles>

Compound 47

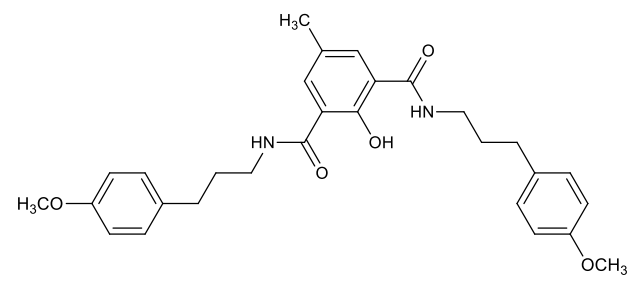

Compound 48 